\title{
ARTIKELEN
}

\section{Lokale democratie: opkomst lokale partijen en politieke fragmentatie}

\author{
Raymond Gradus, Tjerk Budding \& Elbert Dijkgraaf
}

Zowel in de raad als in het college van B\&W zijn lokale politieke partijen duidelijk in opkomst. Hun gemiddeld percentage raadszetels steeg van 25\% in 1998 naar 37\% in 2018 en het percentage wethouders van $21 \%$ naar $32 \%$. Dit viel samen met een sterk toegenomen fragmentatie. Zo is het gemiddeld aantal politieke partijen in de raad gestegen van 6,5 in 1998 tot 8,0 in 2018 en nam in deze periode het aantal partijen dat een of meerdere wethouders levert toe van 2,8 naar 3,4. Fragmentatie uitgedrukt in het aantal effectieve partijen toont een vergelijkbare trend. Als we gebruik maken van de Chapel Hill-score blijkt dat de gemiddelde politieke kleur van zowel de raad als het wethouderdeel in het college naar rechts is verschoven. Dit komt vooral doordat politieke partijen volgens deze index steeds rechtser worden en niet zozeer omdat er lokaal steeds meer op rechtse partijen wordt gestemd. Ook worden er aanzienlijke verschillen in de representatieve vertegenwoordiging geconstateerd. De lokale partijen evenals de SP slagen er minder dan gemiddeld in om hun zetels in de raad om te zetten in wethouderzetels, terwijl de drie grote traditionele (en dan vooral het CDA) en kleinere christelijke partijen hier bovengemiddeld goed in slagen.

Relevantie voor practitioners: dit artikel laat zien dat (a) lokale partijen sinds 1998, zowel in de raad als in het wethouderdeel van het college van B\&W, sterk in opkomst zijn, (b) er een sterke samenhang is tussen het aantal lokale partijen en de fragmentatie van de raad en het wethouderdeel van het college van $B \& W$, en (c) de meerderheid in raadszetels, waarop een gemiddeld college kan rekenen, is gedaald van 63\% in 1998 tot $58 \%$ in 2018.

\section{$1 \quad$ Inleiding}

Zowel landelijk als lokaal neemt de politieke fragmentatie toe. Het aantal politieke partijen in de gemeenteraad stijgt van 6,5 in 1998 naar 8,0 in 2018 en bij de nationale verkiezingen in 2021 zijn er 17 partijen gekozen in het parlement. Op lokaal niveau zien we een samenhang met de opkomst van nieuwe en onafhankelijke lokale partijen, die niet vertegenwoordigd zijn in het nationale parlement. In bijna $80 \%$ van de gemeenten zijn sinds 2018 twee of meer lokale partijen in de gemeenteraad vertegenwoordigd, terwijl dit in 1998 nog 50\% van de gemeenten was. Over de effecten van de politieke fragmentatie op lokaal niveau lopen de meningen uiteen. Volgens Schulz en Frissen (2017) is fragmentatie in zichzelf geen probleem en kan zij leiden tot meer legitimiteit en representativiteit van het lokale bestuur, terwijl anderen aangeven dat de bestuurskracht kan afnemen (zie Lunsing \& Her- 
weijer, 2016). Dit artikel beschrijft deze ontwikkeling aan de hand van data over de politieke samenstelling van het lokaal politiek bestuur over de periode 1998-2018 wat betreft zowel de politieke samenstelling van de gemeenteraden alsmede de colleges van B\&W (hierbij de positie van de burgemeester buiten beschouwing latend). Hierbij wordt in het bijzonder ingegaan op de opkomst van lokale partijen en hun vertegenwoordiging in het college van B\&W. Volgens Van Ostaaijen e.a. (2020) zouden lokale partijen wel de zetels maar niet de macht krijgen. Dit onderzoek wijst in de richting van een toenemende vertegenwoordiging van lokale partijen in het college van B\&W en dus de macht. Daarbij maken we gebruik van de Gids Gemeentebesturen, waarin wordt gerapporteerd over de (politieke) samenstelling van zowel de raad als het college van B\&W. We concentreren ons daarbij op vier vragen, namelijk:

- In welke mate is sprake van de opkomst van lokale politieke partijen zowel in de raad als in het college van B\&W?

- Of en in welke mate is sprake van toenemende fragmentatie in de gemeenteraad en het college van B\&W en wat is de samenhang daartussen?

- Van welke ontwikkeling lijkt sprake te zijn in termen van politieke kleur?

- In welke mate is sprake van een representatieve vertegenwoordiging in het college van B\&W van de diverse politieke partijen?

Nadat in de volgende paragraaf de Nederlandse lokale politiek is geïntroduceerd, zullen in de daaropvolgende paragrafen op basis van empirisch longitudinaal onderzoek de bovenstaande vragen worden beantwoord.

\section{Nederlandse lokale politiek}

In de literatuur is een debat zichtbaar over de status van verkiezingen op lokaal niveau. Vooral in Scandinavische landen zien we dat het aanbod van partijen steeds meer een nationaal karakter krijgt, terwijl het aantal onafhankelijke lokale lijsten afneemt (zie bijvoorbeeld Kjaer \& Elklit, 2010). Voor Denemarken zien zij overigens een sterke samenhang met hervormingen van het lokale bestuur in de jaren zeventig en aan het begin van deze eeuw. Ook in Nederland was in de vorige eeuw het idee dat de vertegenwoordiging in de gemeenteraad steeds meer een nationaal karakter zou krijgen; de opkomst en de toename van onafhankelijke lokale partijen in de laatste twee decennia wijzen echter in een andere richting (zie bijvoorbeeld Steenvoorden e.a., 2017; Gradus \& Budding, 2020).

Feit is dat gemeenten steeds meer taken erbij hebben gekregen en door de burger als meest belangrijke en zichtbare niveau van de overheid worden gezien (Hendriks $\&$ Tops, 2003). Ook zien we dat het gemiddeld aantal inwoners van de gemeenten substantieel is toegenomen. Lag dat nog op 28.566 in 1998, twintig jaar later (in 2018) was dat gestegen naar 45.131. Dit was vooral een gevolg van de herindelingen die hebben plaatsgevonden. Het aantal gemeenten daalde in de periode 19982018 van 548 naar 380 .

Als we kijken naar de politieke actoren binnen gemeenten, dan dient een onderscheid te worden gemaakt tussen de gemeenteraad en het college van B\&W. De le- 
den van de raad worden iedere vier jaar gekozen. In principe, dat wil zeggen tenzij er recent een herindeling heeft plaatsgevonden of juist binnen afzienbare termijn plaatsvindt, vinden deze verkiezingen op de derde woensdag in maart plaats. Het verkiezingsstelsel is gebaseerd op een stelsel van proportionele vertegenwoordiging, waarbij er geen andere kiesdrempel is dan die welke geldt vanwege het minimale aantal stemmen dat nodig is om één zetel in de raad te verkrijgen. Dit getal is gelijk aan het totaal aantal stemmen in een gemeente gedeeld door het aantal zetels in de raad. Otjes (2018) stelt hierover dat dit het Nederlandse systeem relatief open maakt voor het formeren van nieuwe en onafhankelijke lokale partijen.

Het aantal zetels in de raad varieert tussen de 9 (voor gemeenten met minder dan 3001 inwoners) en 45 (voor gemeenten met meer dan 200.000 inwoners). Vanwege de herindelingen die hebben plaatsgevonden, is het totaal aantal raadszetels in de periode 1998-2018 gedaald van 10.129 naar 7924. In dit artikel maken wij in het vervolg een onderscheid tussen nationale en lokale partijen. ${ }^{1}$ Hierbij definiëren wij nationale partijen als partijen die ook vertegenwoordigd zijn in de Tweede Kamer, terwijl lokale partijen dat niet zijn. ${ }^{2} \mathrm{Na}$ de Tweede Kamerverkiezingen in 2017 zijn er 13 nationale partijen: PvdA, VVD, CDA, D66, GroenLinks, SP, ChristenUnie (CU), SGP, PVV, ${ }^{3}$ Partij voor de Dieren, ${ }^{3}$ 50PLUS, ${ }^{4} \mathrm{DENK}^{4}$ en Forum voor Democratie (FvD). ${ }^{4}$

De data voor de samenstelling van de gemeenteraad en het college van $B \& W$ voor de verkiezingsjaren zijn verzameld aan de hand van voorhanden zijnde uitgaven van de Gids Gemeentebesturen, ${ }^{5}$ die jaarlijks wordt uitgegeven door de Vereniging van Nederlandse Gemeenten (VNG).

1 Vergelijkbaar met Otjes (2018) maken we geen onderscheid tussen lokale en regionale partijen, zoals de Fryske Nasjonale Partij (FNP), die in de provinciale staten zijn vertegenwoordigd.

2 Er zijn lokale partijen onder het label 'Leefbaar'. Nu had in 2002 Leefbaar Nederland twee zetels in het nationale parlement. Echter, omdat iedere formele band ontbreekt, zijn deze partijen in navolging van Otjes (2018) bij lokale partijen ingedeeld.

3 PVV en PvdD participeerden in de verkiezingen sinds 2010. Hun relatieve omvang op lokaal niveau is echter beperkt en geen van deze partijen heeft een wethouder. Vandaar dat deze niet worden meegenomen in de gepresenteerde tabellen.

4 Omdat deze partijen alleen participeerden in de verkiezingen in 2018, hebben we deze niet meegenomen in de gepresenteerde tabellen. Hierbij moet worden aangetekend dat hun omvang op lokaal niveau relatief klein is (50PLUS: 34, FvD: 3 en DENK: 21; daarnaast heeft alleen 50PLUS één wethouder).

5 Vanwege beschikbaarheidsissues hebben we gebruik gemaakt van de volgende gidsen: Gemeentegids 2002 (peildatum: september 2001; verkiezingen 1998), Gemeentegids 2004 (peildatum: oktober 2003; verkiezingen 2002), Gemeentegids 2009 (peildatum: oktober 2008; verkiezingen 2006), Gemeentegids 2012 (peildatum: september 2011; verkiezingen 2010), Gemeentegids 2016 (peildatum: januari 2016; verkiezingen 2014), en Gemeentegids 2018 (peildatum: juli 2018) en Gemeentegids 2020 (peildatum: februari 2020) voor verkiezingen 2018. Omdat deze gemeentegidsen (met uitzondering van het laatste jaar) geen betrekking hebben op het jaar van de verkiezingen zelf, maar op een later moment is het aantal waarnemingen per jaar dat we hanteren enigszins lager dan het aantal gemeenten in het jaar van de verkiezingen. 


\section{Opkomst lokale politieke partijen}

In deze paragraaf wordt de eerste subvraag behandeld die betrekking heeft op de mate waarin sprake is van de opkomst van lokale politieke partijen (niet vertegenwoordigd in het nationale parlement) zowel in de raad als in het college van B\&W. In Nederland, maar ook in andere landen, waaronder Zweden (zie Åberg \& Ahlberger, 2015) en Oostenrijk (zie Ennser-Jedenastik \& Hansen, 2013), is er toenemende aandacht voor de opkomst van lokale politieke partijen. Zo geven Peters en Van Stipdonk (2016) aan dat deze in de lokale politiek een steeds grotere (f)actor vormen en in de meeste gemeenten een deel zijn gaan uitmaken van de lokale democratie. Hoewel er soms gedacht wordt dat er sprake is van een nieuw verschijnsel, geven Boogers e.a. (2007) aan dat dit geenszins het geval is. Zo fluctueerde het percentage raadszetels van lokale partijen na de Tweede Wereldoorlog tot aan 1974 tussen de $21 \%$ en $26 \%$. Vooral in de zuidelijke provincies en in de kleine gemeenten elders in Nederland waren de lokale politieke partijen actief. De verklaring die Janssen en Korsten (2003) hiervoor noemen, is dat de Katholieke Volkspartij (KVP) in het zuiden zo dominant was, dat andere landelijke politieke partijen ervoor kozen om zich in diverse gemeenten niet verkiesbaar te stellen. Ook kwam het voor dat de KVP zich van deelname aan verkiezingen onthield, en deze overliet aan lokale politieke partijen (waarin de nodige KVP'ers waren opgenomen) omdat er toch geen sprake was van concurrentie van andere landelijke partijen. Vanaf de jaren zestig veranderde de situatie voor lokale politieke partijen. Ten eerste kwam er meer ruimte voor andere landelijke politieke partijen vanwege de ontzuiling. Ten tweede werd het door de schaalvergroting in het openbaar bestuur beter mogelijk voor landelijke politieke partijen om zich ook lokaal te organiseren (Boogers e.a., 2007).

In tabel 1 wordt het gemiddeld percentage zetels per gemeente, ${ }^{6,7}$ zoals deze bezet worden door de nationale en lokale partijen gepresenteerd, gebaseerd op de gemeenteraadsverkiezingen in 1998, 2002, 2006, 2010, 2014 en 2018. Hieruit kan worden opgemaakt dat het CDA, de VVD en de PvdA de afgelopen twintig jaar een aanzienlijk aantal raadsleden hebben moeten inleveren. Een uitzondering daarop is de gemeenteraadsverkiezing van 2006, waar vooral de PvdA veel zetels wist te winnen. Waar zij in 1998 nog gemiddeld 60\% van de raadszetels innamen, is dit gedaald tot $38 \%$ in 2018 . Daar staat een aanzienlijke winst van lokale politieke partijen tegenover: hun aandeel steeg van $25 \%$ in 1998 naar $37 \%$ in $2018 .{ }^{8}$ De SGP en de CU zagen hun omvang lichtelijk toenemen tussen 1998 en 2018. D66 en GroenLinks werden ook iets groter, alhoewel D66 in 2018 zetels heeft moeten inleveren, vooral aan GroenLinks. Als we naar de SP kijken, zien we dat zij een piek

6 Wij hebben deze gemiddelde percentages berekend door eerst per gemeente het percentage zetels voor de verschillende (groepen) politieke partijen te berekenen en dan het gemiddelde te bepalen. Wij hebben deze aanpak gehanteerd omdat we met name geïnteresseerd zijn in representatie- en fragmentatie-issues per gemeente.

7 Bij een combinatie van partijen (bijv. CU/SGP) is het zetelaantal verdeeld tussen beide partijen.

8 In kleine gemeenten tot 20.000 inwoners is het aandeel lokale partijen in $201844 \%$, voor gemeenten tussen $20.000-50.000$ inwoners is dit $37 \%$, voor $50.000-100.000$-gemeenten is dit $31 \%$ en voor $100.000+$-gemeenten is dit $22 \%$. 
bereikten van 4,2\% in 2014, hetgeen overigens wel een stuk lager is dan hun aandeel bij de landelijke verkiezingen in 2012 (9,6\%). Dit hangt voor een deel waarschijnlijk samen met het feit dat de SP niet in alle gemeenten meedeed. Dit in tegenstelling tot de drie grote traditionele partijen (CDA, VVD en PvdA), die in bijna alle gemeenteraadsverkiezingen participeerden. In tabel 2 is het relatief aantal wethouders per politieke partij aangegeven. Hier is een vergelijkbare ontwikkeling zichtbaar als in tabel 1 . Het relatief aantal wethouders van de traditionele partijen daalde aanzienlijk en dat van lokale politieke partijen steeg fors tussen 1998 en 2018.

Tabel 1 Percentage zetels politieke partijen in de gemeenteraad

\begin{tabular}{lrrrrrrrrr}
\hline & Lokaal & PvdA & VVD & CDA & D66 & GL & SP & CU & SGP \\
\hline 1998 & $24,6 \%$ & $17,8 \%$ & $17,7 \%$ & $24,3 \%$ & $4,1 \%$ & $3,7 \%$ & $1,2 \%$ & $2,9 \%$ & $2,6 \%$ \\
2002 & $29,9 \%$ & $15,1 \%$ & $16,0 \%$ & $24,3 \%$ & $2,7 \%$ & $4,2 \%$ & $1,2 \%$ & $3,9 \%$ & $2,8 \%$ \\
2006 & $27,3 \%$ & $21,7 \%$ & $14,1 \%$ & $21,0 \%$ & $1,6 \%$ & $4,4 \%$ & $2,6 \%$ & $4,4 \%$ & $2,9 \%$ \\
2010 & $30,3 \%$ & $14,1 \%$ & $16,6 \%$ & $18,8 \%$ & $5,6 \%$ & $4,4 \%$ & $2,2 \%$ & $4,3 \%$ & $3,1 \%$ \\
2014 & $34,8 \%$ & $9,3 \%$ & $12,5 \%$ & $18,5 \%$ & $8,3 \%$ & $3,9 \%$ & $4,2 \%$ & $4,8 \%$ & $3,3 \%$ \\
2018 & $36,7 \%$ & $7,3 \%$ & $13,8 \%$ & $17,2 \%$ & $6,9 \%$ & $6,1 \%$ & $3,1 \%$ & $4,6 \%$ & $3,0 \%$ \\
\hline
\end{tabular}

Tabel 2 Percentage zetels politieke partijen in college van B\&W (excl. burgemeester)

\begin{tabular}{rrrrrrrrrr}
\hline & Lokaal & PvdA & VVD & CDA & D66 & GL & SP & CU & SGP \\
\hline 1998 & $20,6 \%$ & $21,7 \%$ & $19,8 \%$ & $29,7 \%$ & $1,8 \%$ & $1,7 \%$ & $0,1 \%$ & $2,5 \%$ & $2,0 \%$ \\
2002 & $24,7 \%$ & $18,0 \%$ & $16,1 \%$ & $29,6 \%$ & $2,1 \%$ & $2,7 \%$ & $0,6 \%$ & $3,4 \%$ & $2,4 \%$ \\
2006 & $17,9 \%$ & $27,8 \%$ & $14,7 \%$ & $25,2 \%$ & $1,4 \%$ & $4,3 \%$ & $1,4 \%$ & $4,8 \%$ & $2,5 \%$ \\
2010 & $25,5 \%$ & $15,1 \%$ & $19,7 \%$ & $21,7 \%$ & $5,6 \%$ & $3,9 \%$ & $1,0 \%$ & $4,4 \%$ & $3,2 \%$ \\
2014 & $28,9 \%$ & $9,2 \%$ & $13,2 \%$ & $23,3 \%$ & $9,1 \%$ & $3,9 \%$ & $2,8 \%$ & $5,5 \%$ & $3,8 \%$ \\
2018 & $31,6 \%$ & $7,6 \%$ & $15,7 \%$ & $21,5 \%$ & $6,5 \%$ & $6,0 \%$ & $1,6 \%$ & $5,4 \%$ & $3,5 \%$ \\
\hline
\end{tabular}

\section{Fragmentatie}

In deze paragraaf wordt de tweede subvraag behandeld, die betrekking heeft op de mate van politieke fragmentatie. Naast de hiervoor gedocumenteerde (hernieuwde) opkomst van lokale politieke partijen is er ook sprake van toenemende politieke fragmentatie. Dat deze fragmentatie ook aanzienlijke gevolgen kan hebben voor politieke besluitvorming komt naar voren uit enige eerdere onderzoeksprojecten. Zoals ook Lunsing en Herweijer (2016) laten zien, hangt dit sterk af van het onderwerp en in hoeverre ideologische verschillen tussen politieke partijen het moeilijker maken om tot overeenstemming te komen. Goeminne e.a. (2008) laten voor Vlaamse gemeenten zien dat gefragmenteerde gemeenten (gemeten door het aantal partijen in het college) optimistischer zijn in het voorspellen van de belastinginkomsten en daarom hogere tekorten hebben. Warner en Hefetz (2002) constateerden voor Amerikaanse lokale overheden dat gefragmenteerde gemeenten minder vaak tot uitbesteding overgaan. Voor Nederlandse gemeenten vonden Gra- 
dus en Budding (2020) echter indicaties voor het omgekeerde. Lunsing en Herweijer (2016) gingen op basis van de uitslagen van de gemeenteraadsverkiezingen in 2014 na in welke mate er sprake was van fragmentatie bij de Nederlandse gemeenten en welke gevolgen deze fragmentatie had. Hierbij constateerden zij aan de hand van correlatieanalyse dat een hogere mate van fragmentatie samenhangt met een relatief hogere schuld per inwoner en een beperktere mate van gescheiden inzameling van huishoudelijk afval. Iets vergelijkbaars werd gevonden in een studie van Gradus en Dijkgraaf (2019), die op basis van een regressieanalyse laten zien dat gefragmenteerde gemeenten minder snel overgaan tot afvalbeprijzing. Kortom, er zijn aanwijzingen dat fragmentatie invloed kan hebben op besluitvormingsprocessen bij gemeenten en het dus van belang is om de ontwikkelingen op het vlak van fragmentatie te kunnen schetsen.

In deze studie analyseren we fragmentatie met behulp van twee kengetallen. In de eerste plaats meten we de fragmentatie door te kijken naar het aantal politieke partijen in de gemeenteraad en het politieke deel van het college van B\&W (zie Lunsing \& Herweijer, 2016). Vooral de grote gemeenten kennen een groot aantal politieke partijen in de raad en het politieke deel van het college van B\&W. Zo heeft de gemeenteraad van Den Haag sinds de verkiezingen in 201815 partijen in de gemeenteraad en heeft Rotterdam een college van B\&W bestaande uit 10 wethouders en 6 partijen. In de gemeenteraad van Den Haag zijn 6 lokale partijen vertegenwoordigd, die niet in het nationale parlement zitten. Ten tweede brengen we de fragmentatie in beeld, waarbij we corrigeren voor de relatieve omvang van de partijen. Dat doen we door rekening te houden met verschillen in de relatieve omvang van de partijen, en we hanteren hierbij de volgende formule (zie Mueller, 2003: 273; Laakso \& Taagepera, 1979):

$C=1 / \sum_{i=1}^{n} x_{i}^{2}$

Hierbij staat $\mathrm{x}_{\mathrm{i}}$ voor het percentage zetels (in de gemeenteraad of in het wethouderdeel van het college van $B \& W$ ) van partij i. Deze index meet het effectieve aantal politieke partijen en wordt wel de Laakso-Taagepera-index genoemd.

Figuur 1 brengt de stijgende politieke fragmentatie in de afgelopen decennia in beeld. Het absoluut aantal politieke partijen in de gemeenteraad steeg van 6,5 in 1998 naar 8,0 in 2018. Uitgedrukt in het aantal effectieve partijen steeg dit van 4,8 in 1998 naar 6,0 in 2018. Als we kijken naar het college van B\&W, dan zien we het absoluut aantal partijen dat wethouders levert, stijgen van 2,8 in 1998 naar 3,4 twintig jaar later. Geëxpliciteerd in het effectief aantal partijen dat vertegenwoordigd is in het college van B\&W gaat het om een verandering van 2,7 naar 3,3. 
Figuur 1 Absoluut en effectief aantal politieke partijen in de raad en het college van $B \& W$

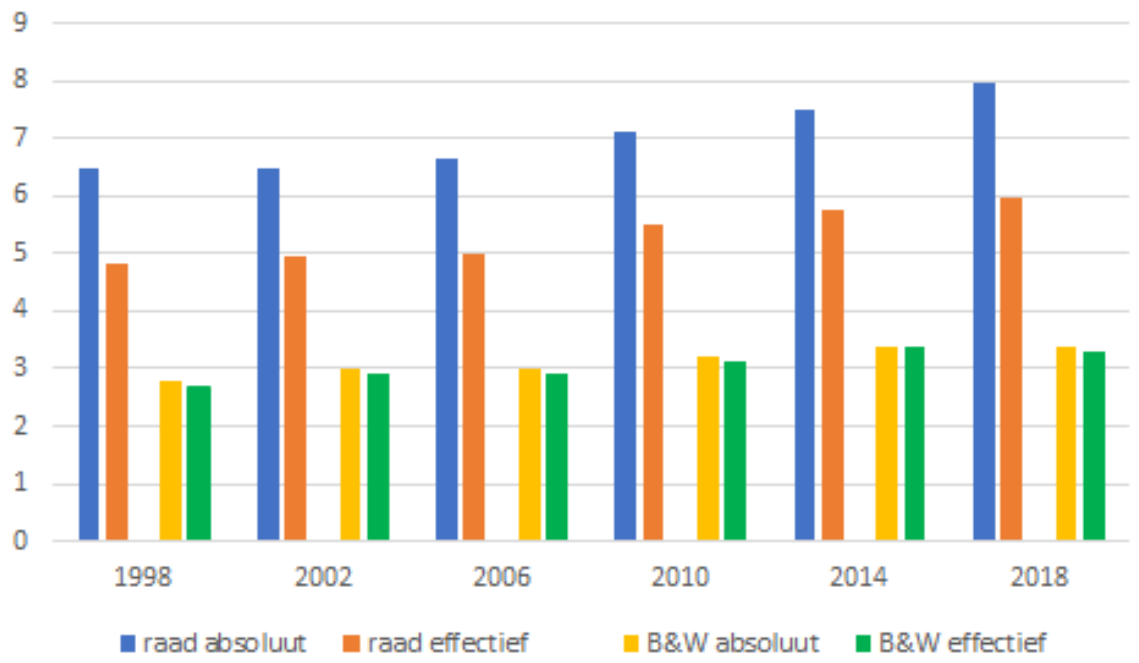

De fragmentatie kan niet alleen worden toegeschreven aan de verminderde populariteit van de drie traditionele partijen (zoals we gezien hebben in paragraaf 3 ), maar ook aan een stijging van het aantal lokale politieke partijen. Uit tabel 3 kan worden opgemaakt dat het gemiddeld aantal lokale politieke partijen is gestegen van 1,75 in 1998 naar 2,50 in 2018 . Waarbij er in 1998 nog sprake van was dat $17 \%$ van de gemeenten geen enkele lokale politieke partij had, is dit percentage in 2018 gedaald tot bijna nihil (2\%). Het percentage gemeenten met één lokale politieke partij daalde van 34\% in 1998 naar 21\% in 2018. Daar staat echter tegenover dat het percentage gemeenten met twee, drie of vier lokale politieke partijen steeg van respectievelijk 26\%, 13\% en 5\% in 1998 naar 40\%, 27\% en $13 \%$ in 2018 . We zien derhalve dat met name het aantal gemeenten met drie of vier lokale politieke partijen sterk toenam tussen 1998 en 2018.

Tabel 3 Aantal gemeenten met het aantal lokale politieke partijen

\begin{tabular}{lrrrrrr}
\hline Partijen & $\mathbf{1 9 9 8}$ & $\mathbf{2 0 0 2}$ & $\mathbf{2 0 0 6}$ & $\mathbf{2 0 1 0}$ & $\mathbf{2 0 1 4}$ & $\mathbf{2 0 1 8}$ \\
\hline 0 & $16,8 \%$ & $9,1 \%$ & $6,4 \%$ & $4,8 \%$ & $2,9 \%$ & $2,0 \%$ \\
1 & $33,7 \%$ & $34,3 \%$ & $31,0 \%$ & $31,3 \%$ & $23,6 \%$ & $21,4 \%$ \\
2 & $26,1 \%$ & $29,3 \%$ & $32,3 \%$ & $31,5 \%$ & $29,9 \%$ & $30,1 \%$ \\
3 & $12,8 \%$ & $15,7 \%$ & $17,7 \%$ & $17,9 \%$ & $22,9 \%$ & $27,3 \%$ \\
4 & $5,0 \%$ & $4,7 \%$ & $7,6 \%$ & $10,3 \%$ & $15,1 \%$ & $13,2 \%$ \\
5 & $3,8 \%$ & $4,3 \%$ & $3,4 \%$ & $2,9 \%$ & $3,6 \%$ & $3,4 \%$ \\
6 of meer & $1,9 \%$ & $2,5 \%$ & $1,6 \%$ & $1,4 \%$ & $2,1 \%$ & $2,6 \%$ \\
Gemiddeld aantal partijen & 1,75 & 1,97 & 2,07 & 2,12 & 2,44 & 2,50 \\
\hline
\end{tabular}


Er is een sterke samenhang tussen de fragmentatie van de raad en het college van $B \& W$. Uit een door ons uitgevoerde correlatieanalyse tussen fragmentatie van de raad en die van het college van B\&W komt een (Pearson) correlatiecoëfficiënt naar voren van 0,66 $(p<0,01)$. Naast dat de fragmentatie tussen de raad en het college van B\&W onderling sterk samenhangt, is dat ook het geval tussen het aantal lokale politieke partijen dat actief is in een gemeente en de mate van fragmentatie. Wij vinden hierbij een correlatiecoëfficiënt van $0,52(p<0,01)$ voor de samenhang tussen het aantal lokale politieke partijen in de raad en de fragmentatie van de raad. Als we deze zelfde samenhang bekijken voor het college van B\&W komen we op een correlatiecoëfficiënt van $0,30(p<0,01)$. Met andere woorden, de toename van het aantal lokale politieke partijen heeft geleid tot meer versnippering in zowel de raad als het college van B\&W.

\section{$5 \quad$ Politieke kleur}

In deze paragraaf wordt de subvraag over politieke kleur besproken. In paragraaf 3 kwam reeds naar voren dat er een trend zichtbaar is van een daling in vertegenwoordiging van de drie traditionele partijen en een opkomst van de lokale politieke partijen. Om er nader zicht op te krijgen wat dit betekent in termen van de politieke kleur van gemeenten, maken wij gebruik van de zogeheten Chapel Hill Expert Survey (www.chesdata.eu). Deze survey is voor het eerst uitgezet in 1999, en daarna in de jaren 2002, 2006, 2010, 2014 en 2019. Nederland maakt samen met dertien andere West-Europese landen onderdeel uit van de groep die hierbij vanaf het begin van dit onderzoek in beschouwing wordt genomen. In de loop der jaren is de onderzoekspopulatie verbreed en in het meest recente jaar (2019) waarvoor gegevens beschikbaar zijn, vormden alle EU-lidstaten, tezamen met Noorwegen, Zwitserland en Turkije, onderdeel van deze groep. De twee hoofddoelen van de Chapel Hill Expert Survey zijn het in beeld brengen van (1) de ideologische positionering van politieke partijen op de klassieke links-rechtsdimensie (alsmede enige andere dimensies, zoals standpunten ten aanzien van economische vraagstukken) en (2) de standpunten van politieke partijen over de Europese Unie (Bakker e.a., 2015). Om de data te verzamelen maken de onderzoekers gebruik van een vragenlijst onder wetenschappers.

Voor ons artikel hebben we voor ieder verkiezingsjaar gebruik gemaakt van de meest recent beschikbare scores voor de nationale politieke partijen op een links-rechtsdimensie. ${ }^{9}$ Omdat voor de lokale politieke partijen geen Chapel Hill-score beschikbaar is, laten we deze buiten de berekening van de Chapel Hill-index. Voor de overige partijen geldt dat hoe dichter zij bij de score 1 zitten, hoe rechtser deze partij wordt gezien. Zo hebben de bevraagde experts de VVD in 2017 een gemiddelde score van 0,84 gegeven en de SP van 0,11. Daarbij past wel de kant-

9 De vraagstelling voor deze dimensie luidt als volgt (voor de survey in 2010, zie Bakker e.a., 2015):

'We now turn to a few questions on the ideological positions of political parties in [country] in 2010. Please tick the box that best describes each party's overall ideology on a scale ranging from 0 (extreme left) to 10 (extreme right).' Omdat de eerste survey in 1999 plaatsvond, gebruiken we voor 1998 de uitkomsten uit 1999. 
tekening dat voorbij wordt gegaan aan mogelijke verschillen tussen de links-rechtspositie van de nationale partij in de index (die is gebaseerd op de landelijke issues) en de links-rechtspositionering van lokale afdelingen van nationale partijen (ten aanzien van lokale issues).

Tabel 4 Politieke kleur op basis van Chapel Hill-index ( $0=$ links, $1=$ rechts $)$

\begin{tabular}{lll}
\hline & Politieke kleur $\mathbf{( C H})$ \\
\hline 1998 & Raad & College \\
2002 & 0,54 & 0,56 \\
2006 & 0,57 & 0,58 \\
2010 & 0,53 & 0,53 \\
2014 & 0,58 & 0,59 \\
2018 & 0,58 & 0,60 \\
\hline
\end{tabular}

Uit tabel 4 komt een aantal ontwikkelingen naar voren. Ten eerste blijkt dat de Chapel Hill-score van 1998 naar 2018 is toegenomen. Bij de raad gaat het om een stijging van 0,54 in 1998 naar 0,60 in 2018 en voor de wethouders van 0,56 naar 0,63 . Kortom, zowel de raad als het politieke deel van het college van B\&W lijkt flink rechtser te zijn geworden. De scores van 1998 en 2018 verschillen ook sterk $(p<0,00)$ statistisch significant van elkaar. Als we echter corrigeren voor de wijzigingen van de voorkeuren binnen de verschillende politieke partijen in de loop der jaren, en de Chapel Hill-index per politieke partij constant houden op het niveau dat gold op het moment van de gemeenteraadsverkiezingen in 1998, dan zien we dat de score bij zowel de raad als het college van B\&W nagenoeg gelijk is gebleven (in 2018 respectievelijk 0,53 en 0,56). Hieruit komt het beeld naar voren dat het bij de 'verrechtsing' vooral gaat om een verschuiving van politieke partijen op de links-rechtsdimensie en niet zozeer om meer stemmen op 'rechtse' partijen. Illustratief in dit verband is dat de Chapel Hill-score van de VVD toenam van 0,69 in 1998 naar 0,84 in 2017.

Ten tweede zien we een aanzienlijk verschil tussen de raad aan de ene kant en de wethouders aan de andere kant. Voor bijna alle jaren geldt dat de gemiddelde politieke kleur van het college van B\&W (voor zover het de wethouders betreft) rechtser is dan die van de raad. Overigens geldt dit niet voor het jaar 2006, waarbij de politieke kleur van zowel de raad als het college van B\&W minder rechts was dan in andere jaren. Dit lijkt met name te maken te hebben met de gunstige verkiezingsuitslag voor de PvdA in dat jaar, en in mindere mate geldt dit ook voor de SP (zie tabel 2 en 3 ).

\section{Representatieve vertegenwoordiging}

Tot slot wordt in deze paragraaf de politieke representatie in het college beschreven. Een gangbaar democratisch uitgangspunt is dat in de samenstelling van het bestuur de voorkeuren van de bevolking worden gerepresenteerd (Thomassen, 
1981). Een manier om dit uit te drukken is het verschil tussen zetels en vertegenwoordiging in het college (zie tabel 5).

Tabel 5 Representatieve vertegenwoordiging

\begin{tabular}{|c|c|c|c|c|c|c|c|c|c|c|}
\hline & \multicolumn{9}{|c|}{ Verschil tussen percentage zetels in de raad en in het college van B\&W } & \multirow[t]{2}{*}{ Macht } \\
\hline & $\begin{array}{l}\text { Lokale } \\
\text { partijen }\end{array}$ & PvdA & VVD & CDA & D66 & GL & SP & CU & SGP & \\
\hline 1998 & $4,0 \%$ & $-3,9 \%$ & $-2,1 \%$ & $-5,4 \%$ & $2,3 \%$ & $2,0 \%$ & ।, I\% & $0,4 \%$ & $0,6 \%$ & 0,63 \\
\hline 2002 & $5,1 \%$ & $-2,9 \%$ & $-0,1 \%$ & $-5,3 \%$ & $0,6 \%$ & $1,5 \%$ & $0,6 \%$ & $0,5 \%$ & $0,4 \%$ & 0,63 \\
\hline 2006 & $9,4 \%$ & $-6,1 \%$ & $-0,6 \%$ & $-4,2 \%$ & $0,2 \%$ & $0,1 \%$ & 1,2\% & $-0,4 \%$ & $0,4 \%$ & 0,61 \\
\hline 2010 & $4,8 \%$ & $-1,0 \%$ & $-3,1 \%$ & $-2,9 \%$ & $0,0 \%$ & $0,5 \%$ & ।,2\% & $-0,1 \%$ & $-0,1 \%$ & 0,60 \\
\hline 2014 & $5,9 \%$ & $0,1 \%$ & $-0,7 \%$ & $-4,8 \%$ & $-0,8 \%$ & $0,0 \%$ & 1,4\% & $-0,7 \%$ & $-0,5 \%$ & 0,60 \\
\hline 2018 & $5,0 \%$ & $-0,3 \%$ & $-1,9 \%$ & $-4,3 \%$ & $0,4 \%$ & $0,1 \%$ & 1,5\% & $-0,8 \%$ & $-0,5 \%$ & 0,58 \\
\hline
\end{tabular}

Uit tabel 5 kan worden opgemaakt dat bij alle verkiezingen lokale politieke partijen relatief meer zetels hebben verworven dan dat zij zetels in het pluche mogen leveren. Dit verschil loopt uiteen tussen $4,0 \%$ en $9,4 \%$ (zie tabel 2). Opvallend is dat hoewel de populariteit van lokale politieke partijen is gestegen, dit verschil ongeveer gelijk is gebleven, met uitzondering van het jaar 2006. Ook de SP slaagt er in de praktijk niet altijd in raadszetels om te zetten in posities in het college van B\&W. Het omgekeerde beeld is zichtbaar bij het CDA. Zij leveren consistent meer wethouders dan dat ze zetels in de raad verwerven. Ook de VVD levert consistent meer wethouders, zij het dat het aantal wel kleiner is dan bij de christendemocraten.

In navolging van Vanneste en Goeminne (2020) hebben we ook een variabele berekend, die de macht van het college van B\&W weergeeft. In principe zullen colleges moeten steunen op ten minste de helft van het aantal zetels in de gemeenteraad. In veel colleges zal de meerderheid groter zijn dan $50 \%$. In tabel 5 is te zien dat de meerderheid waarop een gemiddeld college kan rekenen, afneemt van 63\% in 1998 tot $58 \%$ in 2018. Daarnaast blijkt uit onze dataset dat het percentage gemeenten waarbij sprake is van een 'minderheidskabinet' (oftewel: de macht is kleiner dan $50 \%$ ) gemiddeld genomen rond de $10 \%$ is. Overigens lopen de oorzaken van een dergelijke situatie uiteen. Ten eerste zou het kunnen gaan om gemeenten waarin niet alle coalitiepartijen zijn vertegenwoordigd in het college. Dit zal ook door de toegenomen fragmentatie steeds vaker het geval zijn. Hierbij speelt ook dat bij kleine gemeenten slechts een beperkt aantal wethouders aangesteld mag worden. Zo bepaalt artikel 36 van de Gemeentewet dat een gemeente met maximaal 6000 inwoners maximaal twee fulltime (en maximaal drie parttime) wethouders mag aanstellen. Volgens Schulz en Frissen (2017) zijn er twee manieren waarop met deze situatie om kan worden gegaan: (1) gezamenlijke benoeming van wethouders en (2) opvolging in de tijd (bijvoorbeeld halverwege de collegeperiode). Ten tweede kan het gaan om een gemeente waarbij er een tijdelijke vacature voor een wethouderspositie is. 


\section{Conclusie}

In dit artikel hebben we de politieke samenstelling van de gemeenteraad en het college van B\&W weergegeven van 1998 tot 2018. Daarbij hebben we gebruik gemaakt van de Gids Gemeentebesturen, op basis waarvan een betrouwbaar beeld naar voren kwam van de samenstelling van zowel de raad als het college van B\&W. Zowel in de raad als in het bestuur zijn de lokale politieke partijen duidelijk in opkomst. Hun gemiddeld percentage raadszetels steeg van 25\% in 1998 naar 37\% in 2018 en het percentage wethouders van $21 \%$ naar $32 \%$. Daarnaast nam het gemiddeld aantal lokale politieke partijen per gemeente aanzienlijk toe, te weten van 1,75 naar 2,50. Hier staat tegenover dat met name de grote traditionele politieke partijen (CDA, VVD en PvdA) sterk aan populariteit hebben ingeboet. Waar deze drie partijen in 1998 nog gemiddeld 60\% van de raadszetels bij een gemeente innamen, is dit in 2018 gedaald tot $38 \%$.

In het tweede thema nemen we op basis van onze analyses een sterk toegenomen fragmentatie waar, zowel van de raad als van het college. Zo is het gemiddeld aantal politieke partijen in de raad gestegen van 6,5 in 1998 tot 8,0 in 2018 en was deze stijging van 2,8 in 1998 naar 3,4 in 2018 voor het aantal partijen dat een of meerdere wethouders levert. Fragmentatie uitgedrukt in het aantal effectieve partijen steeg van 4,8 in 1998 naar 6,0 in 2018 voor de raad en van 2,7 in 1998 naar 3,3 in 2018 voor het college. Ook is de samenhang tussen de fragmentatie van de raad en het college onderzocht. Op basis van een correlatieanalyse zien we een sterke samenhang (zoals in het publieke debat vaak wordt verondersteld). Ook zien we een aanzienlijk verband tussen het aantal lokale politieke partijen en de fragmentatie van de raad en het college van $B \& W$.

Het derde thema dat we hebben besproken, betreft wijzigingen in de politieke kleur van de lokale politiek. Hierbij hebben we gebruik gemaakt van de Chapel Hill-score. Uit onze analyses blijkt dat de gemiddelde politieke kleur van zowel de raad als het politieke deel van het college van B\&W naar rechts is verschoven. Dit komt vooral doordat politieke partijen steeds rechtser worden en niet zozeer doordat er steeds meer op rechtse partijen wordt gestemd.

Een laatste thema dat is behandeld, is dat van representatieve vertegenwoordiging: in hoeverre worden in de samenstelling van het bestuur de voorkeuren van de bevolking gerepresenteerd? Wij analyseren dit door na te gaan in hoeverre het aantal wethouders dat een politieke partij mag leveren, correspondeert met het aandeel in de raad. Uit onze analyses blijkt dat met name de lokale politieke partijen (evenals de SP) er minder dan gemiddeld in slagen om hun zetels in de raad om te zetten in zetels in het college, terwijl de drie grote traditionele partijen (en dan vooral het CDA) hier bovengemiddeld goed in slagen. Ten slotte hebben we gezien dat de meerderheid waarop coalities kunnen rekenen, gemiddeld gesproken afneemt van $63 \%$ in 1998 tot $58 \%$ in 2018 . In grote steden was deze trend al langer zichtbaar. In toekomstig onderzoek zou het interessant zijn om de relatie tussen de toenemende fragmentatie en afnemende machtsbasis van coalities en gemeentelijke besluitvormingsprocessen verder te duiden. Al met al hopen we met dit artikel een vooral 
empirische bijdrage te hebben geleverd aan een beter beeld van hoe de democratie op lokaal niveau functioneert en welke ontwikkelingen daarbij in de tijd zichtbaar zijn. Verder onderzoek kan de in dit onderzoek gepresenteerde trends verder duiden.

\section{Literatuur}

Åberg, M. \& C. Ahlberger, 'Local candidate lists: historical artefacts or a novel phenomenon? A research note', Party Politics, 2015/5, p. 813-820.

Bakker, R., C. de Vries, E. Edwards, L. Hooghe, S. Jolly, G. Marks, J. Polk, J. Rovny, M. Steenbergen \& M.A. Vachudova, 'Measuring party positions in Europe. The Chapel Hill expert survey trend file, 1999-2010', Party Politics, 2015/1, p. 143-152.

Boogers, M.J.G.J.A., A.P.M. Lucardie \& G. Voerman, Lokale politieke groeperingen. Belangenbehartiging, protest en lokalisme, Tilburg/Groningen: 2007.

Ennser-Jedenastik, L. \& M.E. Hansen, 'The contingent nature of local party system nationalisation. The case of Austria 1985-2009', Local Government Studies, 2013/6, p. 777-791.

Goeminne, S., B. Geys \& C. Smolders, 'Political fragmentation and projected tax revenues. Evidence from Flemish municipalities', International Tax and Public Finance, 2008/3, p. 297-315.

Gradus, R.H.J.M. \& G.T. Budding, 'Political and institutional explanations for increasing re-municipalization', Urban Affairs Review, 2020/2, p. 538-564.

Gradus, R.H.J.M. \& E. Dijkgraaf, 'Poorer and less political fragmented Dutch municipalities take tighter waste reductions decisions', Waste Management, 2019/3, p. 328-336.

Hendriks, F. \& P.W. Tops, 'Local public management reforms in the Netherlands: fads, fashions and winds of change', Public Administration, 2003/2, p. 301-323.

Janssen, J.I.H. \& A.F.A. Korsten, 'De wederopstanding van lokale lijsten', Bestuurswetenschappen, 2003/2, p. 90-112.

Kjaer, U. \& J. Elklit, 'Party politicisation of local councils. Cultural or institutional explanations for trends in Denmark 1966-2005', European Journal of Political Research, 2010/3, p. 337-358.

Laakso, M. \& R. Taagepera, 'Effective number of political parties. A measure with applications in Western Europe', Comparative Political Studies, 1979/1, p. 3-27.

Lunsing, J.R. \& M. Herweijer, 'Politieke fragmentatie in Nederlandse gemeenten', Bestuurswetenschappen, 2016/1, p. 5-16.

Mueller, D.C., Public choice III, Cambridge: 2003.

Ostaaijen, J.J.C. van, M. Peeters \& S. Jennissen, Bekend op straat en in de raad. Verkennend onderzoek naar de succesfactoren van nieuwe lokale politieke partijen, Tilburg: 2020.

Otjes, S.P., 'Pushed by national politics or pulled by localism? Voting for independent local parties in the Netherlands', Local Government Studies, 2018/3, p. 305-328.

Peters, K. \& V.P. van Stipdonk, 'Hoe staat de lokale democratie in Nederland ervoor?', Bestuurswetenschappen, 2016/4, p. 27-49.

Schulz, J.M. \& P.H.A. Frissen, Politieke fragmentatie. Balanceren tussen effectiviteit, legitimiteit en representativiteit, NSOB, Den Haag: 2017.

Steenvoorden, E., B. Broekema \& J. van der Waal, 'Lokale verkiezingen. Een lokaal of nationaal feest der democratie?', Bestuurswetenschappen, 2017/3, p. 28-50.

Thomassen, J.J.A. (red.), Democratie. Theorie en praktijk, Alphen aan den Rijn: 1981.

Vanneste, S. \& S. Goeminne, 'The role of the past in public policy. Empirical evidence of the long-term effect of past policy and politics on the local budget balance', Economics of Governance, 2020, Volume 21, p. 75-99.

VNG, Gids Gemeentebesturen 2002, Den Haag: 2002. 
VNG, Gids Gemeentebesturen 2004, Den Haag: 2004.

VNG, Gids Gemeentebesturen 2009, Den Haag: 2009.

VNG, Gids Gemeentebesturen 2012, Den Haag: 2012.

VNG, Gids Gemeentebesturen 2016, Den Haag: 2016.

VNG, Gids Gemeentebesturen 2020, Den Haag: 2020.

Warner, M.E. \& A. Hefetz, 'Applying market solutions to public services. An assessment of efficiency, equity, and voice', Urban Affairs Review, 2002/1, p. 70-89. 